\title{
Sensitivity Enhancement of Multidrug Resistant Urinary Tract Escherichia c, oli Isolate to Some Commonly Used Antibiotics after Treatment with Non-Toxic Laboratory Concentrations of Homodium Bromide
}

\author{
OTAJEVWO, F. D \\ Department of microbiology \& biotechnology, western delta university, Oghara, Nigeria.
}

\begin{abstract}
Antibiotic sensitivity testing was carried out invitro on fifteen pure culture strains of Escherichia coli labeled $\mathrm{EC}_{1}-\mathrm{EC}_{15}$ isolated from male midstream urine samples obtained from the Medical Microbiology department of the University of Benin Teaching Hospital, Benin City, Nigeria. Eleven $\left(73.3 \%\right.$ ) of the strains resisted $8(67.7 \%)$ of antibiotics used. $\mathrm{EC}_{8}$ strain was randomly selected for sensitivity enhancement by treatment with non-toxic laboratory concentrations of $0.25-1.05 \mathrm{ug} / \mathrm{ml}$ homodium bromide and incubation done at $37^{\circ} \mathrm{C}$ for 6hours, 12hours, 18hours and 24hours separately. $\mathrm{EC}_{8}$ strain susceptibility profile was determined before treatment with $\mathrm{HmBr}$. Before treatment, whereas $\mathrm{EC}_{8}$ strain was resistant to $8(72.8 \%)$ of antibiotics used, it was sensitive to only $3(27.2 \%)$ which included gentamicin, nitrofurantoin and streptomycin. Mean zones of inhibition recorded for the three antibiotics after $6,12,18$ and 24 hours incubation were $0.73 \mathrm{~mm}, 0.87 \mathrm{~mm}, 1.53 \mathrm{~mm}$ and $2.07 \mathrm{~mm}$ respectively. After treatment and 6hours incubation, $0.35,0.45,0.85$ and $0.95 \mathrm{ug} / \mathrm{ml} \mathrm{HmBr}$ concentrations produced significant sensitivity enhancements of $2.83 \pm 1.58 \mathrm{~mm}, 1.40 \pm 0.86 \mathrm{~mm}$, $2.53 \pm 0.29 \mathrm{~mm}$ and $1.20 \pm 0.50 \mathrm{~mm}$ respectively $(\mathrm{P}<0.05)$ of which sensitivity enhancements by 0.85 and $0.95 \mathrm{ug} / \mathrm{ml} \mathrm{HmBr}$ dilutions were highly significant $(\mathrm{P}<0.01)$. After treatment and 12hours incubation, $0.35, \quad 0.45,0.85$ and $0.95 \mathrm{ug} / \mathrm{ml}$ dilutions produced significant enhancements $(\mathrm{P}<0.05)$ with enhancements produced by 0.85 and $0.95 \mathrm{ug} / \mathrm{ml}$ dilutions being highly significant $(\mathrm{P}<0.01)$. While there was no highly significant sensitivity enhancement $(\mathrm{P}<0.01)$ after 18 hours incubation, only $0.35 \mathrm{ug} / \mathrm{ml}$ dilution produced significant enhancement $(\mathrm{P}<0.05)$ of $2.40 \pm 1.49 \mathrm{~mm}$. There was no record of highly significant enhancements at all $(\mathrm{P}<0.01)$ after 24hours incubation. A four fold $(2.5 \mathrm{ug})$, two fold $(5 \mathrm{ug})$, two fold $(5 \mathrm{ug})$, four fold $(2.5 \mathrm{ug})$ and four fold $(2.5 \mathrm{ug})$ reductions in minimum inhibitory concentration (MIC) of gentamicin were produced by $\mathrm{HmBr}$ dilutions of $0.35,0.45,0.75,0.85$ and $0.95 \mathrm{ug} / \mathrm{ml}$ respectively. Mean percentage sensitivity enhancements of multidrug resistant $\mathrm{EC}_{8}$ to gentamicin, nitrofurantoin and streptomycin at 6, 12, 18 and 24hours incubation after treatment were 171.7\%, $138.9 \%, 57.4 \%$ and $50.8 \%$ respectively. Results suggest a general role for the use of 0.85 and $0.95 \mathrm{ug} / \mathrm{ml}$ $\mathrm{HmBr}$ concentrations as enhancers of non-specific bacterial permeability to antimicrobial agents of which these dilutions may be incorporated into antibiotics during production for enhanced therapeutic performance when consumed in situ.
\end{abstract}




\section{INTRODUCTION}

Antibiotic resistance is a problem that continues to challenge the healthcare sector. Epidemiological studies have suggested that antibiotic resistance genes emerge in microbial populations within 5years of the therapeutic introduction of an antibiotic (Chakrabarty et al., 1990). Antimicrobial resistance is on the rise in Europe and all over the World with gradual loss of first line antimicrobials. Replacement treatments are more costly, more toxic, need much longer duration of treatment and may require treatment in intensive care units (WHO, 2012). This is compounded by lack of laboratory, diagnostic, quality assurance, regulatory and surveillance capacity as well as lack of control over how antimicrobials are obtained and used.

Drug resistant pathogens are notorious globe trotters as they travel well in infected air passengers and through global trade and food (WHO, 2012). Moreso, the growth of medical tourism has accelerated the international spread of hospital-acquired infections that are frequently resistant to multiple drugs. In particular, multidrug resistance is now common in familiar pathogens such as Escherichia coli, Staphylococcus aureus, Klebsiella pneumoniae etc. Escherichia coli causes about $85 \%$ of community-acquired UTIs, $50 \%$ of nosocomial UTIs and more than $80 \%$ of cases of uncomplicated pyelonephritis (Bergeron, 1995) followed by Klebsiella spp that accounts for 6-17\% of such infections (Nabeela et al., 2004).

Advances in identifying new sources of antibiotic natural products and expanding antibiotic chemical diversity are providing chemical leads for new drugs. Inhibitors of resistance mechanisms and microbial virulence are orthogonal strategies that are also generating new chemicals that can extend the life of existing antibiotics. Numerous classes of antimicrobial agents have become less effective as a result of the emergence of antimicrobial resistance often as a result of the selective pressure of antimicrobial usage (Oskay et al., 2009).

This selective pressure can be attributed to indiscriminate use of antibiotics, complex socioeconomic behavioral antecedents and dissemination of drug resistant pathogens in human medicine (Okeke et al., 1999). Moreover, the disappointing lack of new antimicrobial agents has led to overuse of existing ones leading to the emergence of multi-resistant pathogens (McGowan, 2006).

Antibiotic resistance in bacteria develops either by mutation or acquisition of new genes through a process known as horizontal gene transfer. This involves the transfer of resistance genes among pathogens which are often facilitated by the localization of these genes on plasmids particularly those associated with integrons and transposons (Tenover, 2006). Hence, as the proliferation of multidrug resistant pathogens continue unavoidably within and around us, it is important that their resistance trend be put under check through intensive research and antibiotic surveillance (Akortha and Filgona, 2009).

A bacterial pathogen is described as resistant if the MIC of an antibiotic exceeds that of a discriminatory breakpoint concentration which is based on clinical, pharmacological and microbiological factors including non - toxic concentrations that are achieved by parenteral administration (McGowan and Wise, 2001). The problems of resistant gram positive and gram negative bacteria highlight the urgent need for new drugs with new modes of action and/or combination therapy to treat infections caused by resistant human pathogens like Staph. aureus, Pseudomonas aeruginosa and Mycobacterium tuberculosis (Stavril et al., 2007).

Multiple antimicrobial resistances among gram negative organisms have been a long term and well recognized problem with urinary tract infections. Resistance has been observed in multiple genera including Escherichia coli, Enterobacter, Klebsiella, Proteus, Salmonella, Serratia and Pseudomonas 
spp (Cohen, 1992). The mechanisms whereby bacteria circumvent drug action are many and varied ranging from intrinsic impermeability to acquired resistance involving plasmids, transposons and mutation (Gutmann, 1985).

The antibiotic sensitivities of different strains of E.coli vary widely. As a gram negative organism, E.coli is resistant to many antibiotics that are effective against gram positive organisms (Johnson et al., 2006). E.coli bacteria often carry multiple drug resistance plasmids and under stress, readily transfer those plasmids to other species (Salyers et al., 2004). E.coli is a frequent member of biofilms where many species of bacteria exist in close proximity to each other. This mixing of species allows E.coli strains that are piliated to accept and transfer plasmids from and to other bacteria (Perfeito et al., 2007).

Extended spectrum beta-lactamase producing E.coli are highly resistant to an array of antibiotics and infections by these strains are difficult to treat (Paterson and Bonomo, 2005). In 2009, a gene called "New Delhi metallo-beta lactamase (NDMI)" that gives resistance to the intravenous antibiotic carbapenem was discovered on E.coli in India and Pakistan (Paterson and Bonomo, 2005). Increased concern about the prevalence of this "superbug" strain of NDMI containing E.coli in the United Kingdom has led to calls for further monitoring (Evans et al., 2007).

Virulent strains of E.coli can cause gastro-enteritis, urinary tract infections, pelvic inflammatory disease and neonatal meningitis (Todar, 2007). In rarer cases, virulent strains are also responsible for hemolytic uremic syndrome, peritonitis, mastitis, septicemia and gram negative pneumonia (Todar, 2007). Many of the Escherichia coli strains responsible for urinary tract infections in women can be traced back to E.coli strains from the intestinal tract of cattle (Ramchandani et al., 2005). Many of these organisms were found to be resistant to a variety of antibiotics which often results in increased treatment cost and rehabilitation time.

It is generally accepted that there is a link between the use of antibiotics and the selection for resistance (Woo et al., 2003). Treatment with a single drug usually leads to resistance to that drug but cross resistance to other antibiotics (multidrug resistance) that are structurally and functionally unrelated may also occur (Lewis, 1994). For example, soon after the use of penicillin, Staphylococcus aureus was found to produce penicillinase (beta-lactamase). To overcome this situation, the antibiotic - methicillin was used to replace penicillin and a Staph. aureus resistant to methicillin emerged very quickly (Woo et al., 2003). This pattern was also seen following the use of vancomycin.

The widespread development of resistance to several different antibiotics is generally as a result of lateral or horizontal gene transfer which is a process where DNA can be transferred between individual bacteria through transduction, transformation and conjugation. Conjugation requires cell to cell contact for transfer of mobilizable elements from donor to recipient cell (Droge et al., 1998)

The primary mobile elements are plasmids and conjugative transposons which are broad host range conjugal elements. Plasmids are extrachromosomal DNA elements that replicate independently of the chromosome of the bacterial cell. Plasmids are generally small circular, double stranded molecules that can be identified in a variety of bacterial types (Madigan et al., 2003). Resistance plasmids or R plasmids code for enzymes that can inactivate antibiotics, prevent the uptake of an antibiotic or pump out the particular antibiotic (Neu, 1989). Conjugation of plasmid transfer is common among enterobacteriaceae, Pseudomonas spp and many anaerobic bacteria (Neu, 1992).

Curing is the process of removing plasmids from a bacterial cell. This may be observed with relaxed plasmids when the bacterial cell is grown for successive generations in the absence of a selective agent e.g, antibiotic (Trevors, 1986). The resulting bacteria then become sensitive to the selective agent and it was initially thought that this phenomenon would proffer solution in controlling the development of antibiotic resistance in formerly antibiotic susceptible bacteria. Unfortunately, many plasmids are 
conserved even in the absence of the selective agent and possible reasons for this conservation include the presence of DNA cassettes that encode for stability (Zielenkiewicz and Ceglowsk, 2001).

Antibiotics such as mitomycin, rifampicin and flavophospholipol and DNA intercalating dyes such as acridine and ethidium bromide have been shown to cure many plasmids. A natural DNA intercalating compound is plumbagin (Fuji et al., 1992). In a study evaluating the effect of this plant extract on multi antibiotic resistant bacteria of clinical origin, $14 \%$ of the plasmid containing bacteria exhibited curing (Beg and Ahmad, 2000). This percentage of curing is equivalent to the more widely accepted curing agents such as acridine orange and ethidium bromide (Beg and Ahmad, 2000).

According to Ramesh et al. (2000), novobiocin, ethidium bromide, acriflavine, acridine orange, ascorbic acid and elevated temperatures have been proved to be effective curing agents of which, ascorbic acid (a readily available non-hazardous curing agent) induces approximately $35 \%$ curing rate in many strains of Pedococci organisms.

The various researched curing agents may have several different modes of action. They may affect membrane potential, membrane permeability, protein synthesis and the processing of DNA and eliminating certain types of plasmids (Viljanen and Boratynski, 1991). Some curing compounds block plasmid transfer and such inhibition is dose (concentration) dependent (Zhao et al., 2001). The most effective concentrations of a curing agent depend upon the species being treated, efficiency of the curing agent and the mode of action of that particular compound (Carlton and Brown, 1981).

Acridine orange has shown to cure F plasmids from E.coli and it is suggested that this dye interfers with plasmid replication, stimulating the entire plasmid loss (Salisbury et al., 1972). Using combinations like ethidium bromide and novobiocin or imipramine and methylene blue, resulted in curing six plasmids from Salmonella of avian origin of the 17 strains evaluated (Poppe and Gyles, 1988). Contrary to these results, studies with Lactobacillus plantarum showed that intercalating agents such as acriflavine and ethidium bromide were not as effective as novobiocin in curing plasmids (RuizBarba et al., 1991). Elimination of plasmids with chemical agents is not always a success. Infact, intercalating dyes do not cure large plasmids (Stanisich, 1984).

The mode of action of many of these curing agents is not fully understood. In general, the agents tend to be toxic to the host bacteria. The concentrations at which curing occurs is just slightly lower than the concentration that might inhibit or kill the host organism. Comermycin, novobiocin or rifampicin act as curing agents by inhibition of DNA gyrase or RNA polymerase. Their action inhibits DNA plasmid replication and consequently promotes the very effective degradation or elimination of antibiotic resistant plasmids (Danilevskaya, 1980; Trevors, 1986).

Sodium dodecyl sulphate is an ionic detergent found in household products (Shampoos) and it is widely used as a protein-denaturing compound in electrophoresis systems. Also, it is capable of curing $\mathrm{R}$ and F plasmids in E.coli (Tomoeda et al., 1968). Some curing compounds block plasmid transfer. Epigallocatechin gallate (EGCg) is a tea catechin that is suggested to act by blocking or significantly reducing the transfer of conjugative R plasmids between E.coli species. The inhibition rates of transfer were dose dependent, signifying a $42-67 \%$ inhibition at $50-200 \mathrm{ug} / \mathrm{ml}$ and up to $99 \%$ at $800 \mathrm{ug} / \mathrm{ml}$ (Zhao et al., 2001).

Elevated temperatures $\left(43-44^{\circ} \mathrm{C}\right)$ have been successfully used not only to cure tetracycline resistant and penicillinase positive strains of Staph aureus but also for curing F plasmids from E.coli (May et al., 1964; Stadler and Adelberg, 1972).

It has been reported that certain physical treatments and chemical compounds as well as growth conditions may increase the frequency of elimination of drug resistant $\mathrm{R}$ plasmids resulting in sensitive cells that were previously resistant to antibiotics (Lakshmi et al., 1989). DNA intercalating dyes, sodium dodecyl sulphate (SDS), antibiotics, thymine starvation and elevated temperatures have been used as 
curing systems, having a very successful effect on sensitization of previously resistant bacteria (Chakrabartty et al., 1984; Gupta et al., 1980; Obaseki-Ebor, 1984; Reddy et al., 1986).

Treatments that increase frequency of elimination of plasmids will certainly enhance sensitivity of antibiotics. There is paucity of literature on antibiotic sensitivity enhancement using sub-lethal dilutions of chemical agents. Hence, the aim of this study is to enhance the sensitivity of multidrug resistant urinary tract Escherichia coli urinary tract isolate to some commonly used antibiotics after treatment with non-toxic laboratory concentrations of homodium bromide with the following objectives:

a. Determine the susceptibility patterns of antibiotics selectively used on Escherichia coli pathogen strains after incubation at $37^{\circ} \mathrm{C}$ for 24 hours.

b. Determine sensitivity patterns of multidrug $\mathrm{EC}_{8}$ resistant strain before treatment with homodium bromide after incubation at $37^{\circ} \mathrm{C}$ for $6,12,18$ and 24 hours.

c. Determine antibiograms of multidrug resistant $\mathrm{EC}_{8}$ strain to three antimicrobial agents after invitro treatment with non-toxic laboratory concentrations of homodium bromide and incubation at $37^{\circ} \mathrm{C}$ for $6,12,18$ and 24 hours.

d. Determine homodium bromide dilutions effect on the minimum inhibitory concentration (MIC) of gentamicin on multidrug resistant $\mathrm{EC}_{8}$ strain after 24 hours incubation at $37^{\circ} \mathrm{C}$.

e. Determine mean percentage sensitization enhancement of $\mathrm{MDR} \mathrm{EC}_{8}$ strain to gentamicin, nitrofurantoin and streptomycin before and after treatment with homodium bromide.

\section{MATERIALS AND METHODS Sampling/Processing}

Fifteen pure culture strains of Escherichia coli isolated from mid stream urine samples (all well labeled and stocked on sterile nutrient agar slants) obtained from the Medical Microbiology department of the University of Benin Teaching Hospital, Benin City, Nigeria were used for this study. Samples which were collected from male patients were obtained in March, 2010. Samples had already been processed and those that showed significant pyuria (pus cells $\leq 5 / \mathrm{HPF}$ ) for urine deposits viewed microscopically with X 40 objective lens to confirm on going infection. Samples that showed significant pyuria had been processed further by culturing them on MacConkey agar and Cysteine Lactose Electrolyte Deficient agar (CLED) and inoculated sterile plates were incubated aerobically at $37^{\circ} \mathrm{C}$ for 24hours.

Isolates were identified culturally, morphologically, biochemically and by sugar fermentation Cowan and Steel (1996). Red to pink smooth and convex colonies (on MacConkey agar), mucoid or non-mucoid yellowish smooth and convex colonies (on CLED agar), gram negative bacilli in singles, indole positive, methyl red positive, voges proskauer negative, citrate negative, urease negative, gelatin liquefaction negative colonies with gas from glucose and lactose fermentation were confirmatory of Escherichia coli. All isolated E.coli pathogenic strains were subjected to sensitivity testing.

\section{Sensitivity Testing}

Antibiotic susceptibility testing on the Escherichia coli pathogenic strains was carried out according to the disc diffusion method by Kirby and Bauer (1996). A loopful of a colony was picked aseptically using a flamed wire loop and placed in the centre of a sterile Nutrient agar plate. This was then spread all over the plate applying the caution of not touching the edges of the plate. The seeded plate was allowed to stand for about 2minutes to allow the agar surface to dry. A pair of forceps was flamed and used to pick a multidisc which was aseptically impregnated on the centre of the plate. Discs were placed at least $22 \mathrm{~mm}$ from each other and $14 \mathrm{~mm}$ from the edge of the plate (Ochei and Kolhatkar, 
2008). Antibiotic discs used were selected on the basis of their clinical importance and efficacy on E.coli.

The plate was incubated aerobically at $37^{\circ} \mathrm{C}$ for 24 hours. A reference control strain, Escherichia coli NCTC was inoculated in the same way on another plate with the same antibiotic discs and incubated at same temperature and time. At the end of incubation, the diameters of the zones of inhibition from one edge to the opposite edge were measured to the nearest millimeter using a transparent ruler (Byron et al., 2003). The entire process was repeated for all strains isolated.

Strains that showed resistance against three antibiotics and above were termed multiple drugs resistant (MDR) strains (Jan et al., 2002) and were noted and used for next stage of study. Out of the fifteen strains, strain $\mathrm{EC}_{8}$ was randomly selected for sensitivity enhancement. The idea is that methods and techniques used for $\mathrm{EC}_{8}$ strain can equally be used for any of the other strains and similar results may be obtained.

\section{Preparation of Non toxic Laboratory Concentrations Homodium bromide}

According to Wurmb-Schwark et al. (2006), homodium bromide concentrations of $0.25-1 \mathrm{ug} / \mathrm{ml}$ are safe for laboratory use as they are below toxicity levels. Hence, homodium bromide dilutions of $0.25-1.05 \mathrm{ug} / \mathrm{ml}$ were prepared using $\mathrm{RV} / \mathrm{O}$ where stock or original concentration of $\mathrm{HmBr}$ is $5 \mathrm{mg} / \mathrm{ml}$ and the required concentrations are $0.25,0.35,0.45,0.55,0.65,0.75,0.85,0.95$ and $1.05 \mathrm{ug} / \mathrm{ml}$.

\section{Growing Broth Culture of MDR EC $\mathrm{B}_{8}$ strain}

A colony of multidrug resistant $\mathrm{EC}_{8}$ strain was aseptically picked from slant stock culture using a flamed and cooled wire loop and inoculated into sterile $10 \mathrm{ml}$ Nutrient broth. Inoculated broth was incubated at $37^{\circ} \mathrm{C}$ for 18 hours. The resulting broth culture was then diluted according to a modified method of Shirtliff et al. (2006). Using a sterile pipette, $0.1 \mathrm{ml}$ of broth culture was mixed with $99.9 \mathrm{ml}$ (1:200 dilution) of sterile Nutrient broth. This was properly mixed and was used as working inoculum and should contain $10^{5}-10^{6}$ organisms if used within 30minutes (Ochei and Kolhatkar, 2008).

\section{Treatment of multidrug resistant $\mathrm{EC}_{8}$ strain with dilutions of Homodium bromide}

The treatment of $\mathrm{MDR} \mathrm{EC}_{8}$ strain with the prepared dilutions of Homodium bromide was done according to a modified method of Byron et al. (2003). Using a sterile pasteur pipette, $0.5 \mathrm{ml}$ aliquot of diluted overnight broth culture of $\mathrm{MDR} \mathrm{EC}_{8}$ strain was added to $4.5 \mathrm{ml}$ sterile molten nutrient agar. The various dilutions (one at a time) of Homodium bromide were then added in $0.5 \mathrm{ml}$ volume. The set up was properly mixed and labeled. The set up for each dilution was then poured on top of sterile hardened or set $2 \%$ Nutrient agar plates and left to set.

The same antibiotic multidiscs used before treatment were then picked using flamed and cooled pair of forceps and impregnated on the set agar overlay plates. Plates were incubated at $37^{\circ} \mathrm{C}$ for 6 hours, 12hours, 18hours and 24hours. Measurement of diameters of zones of inhibition at 6hours, 12hours, 18 hours and 24hours were taken and recorded.

\section{Determination of MIC of Gentamicin after Homodium bromide Treatment}

Serial dilutions of gentamicin (one of the three antibiotics whose sensitivity to multidrug $\mathrm{EC}_{8}$ strain was enhanced after homodium bromide treatment) MIC were made in Nutrient broth. Each dilution was inoculated with standard inoculum of the test organism (Ochei and Kolhatkar, 2008). After appropriate incubation, the lowest concentration in the tube showing visual (macroscopic) inhibition of growth is the MIC.

\section{PROCEDURE:}

The multidrug resistant $\mathrm{EC}_{8}$ strain was grown in sterile Nutrient broth and incubated at $37^{\circ} \mathrm{C}$ overnight. The resulting turbid broth culture was diluted 1:200 as previously described. The antibiotic drug (gentamicin) was sterilized by filtration before use. Sterile test tubes, numbering 13 were set up on a test tube rack and labeled 1-13. Using a sterile pipette, $1 \mathrm{ml}$ of diluted broth was dispensed into tubes 2- 
10, 11 and 13. Into tube 12, $2 \mathrm{ml}$ of diluted broth culture was pipetted. Tube 11 was the inoculum control, tube 12 was the broth control and 13 was the drug (gentamicin) control. Into tubes 1, 2 and 13, $1 \mathrm{ml}$ of the working antibiotic solution was pipetted. Serial doubling dilutions of antibiotic solution was separately prepared in Nutrient broth to get reducing concentrations of the antibiotic (i.e, 5, 2.5, 1.25, $0.63,0.32 \mathrm{ug}$ etc since $\mathrm{MIC}$ of gentamicin is $10 \mathrm{ug}$ ). All tubes were incubated at $37^{\circ} \mathrm{C}$ for 18 hours. Turbidity (cloudiness) in the growth medium indicated growth. Tube 11 showed turbidity and tubes 12 and 13 showed no growth. The lowest concentration showing no growth was the MIC of the antimicrobial agent as effective against the multidrug resistant $\mathrm{EC}_{8}$ strain. All MIC results before and after treatment with homodium bromide were recorded accordingly.

\section{RESULTS}

The antibiotic sensitivity reactions of pure strains of Escherichia coli isolate coded as $\mathrm{EC}_{1}-\mathrm{EC}_{15}$ obtained from midstream urine of male patients are shown in Table 1. Strains that showed resistance to three or more of the antibiotics used included $\mathrm{EC}_{1}-\mathrm{EC}_{6}, \mathrm{EC}_{11}-\mathrm{EC}_{13}$ and $\mathrm{EC}_{15}$. Eleven strains of multidrug E.coli showed resistance to $8\left(67.7 \%\right.$ ) of the antibiotics (on average) used. The $\mathrm{EC}_{8}$ strain selected showed resistance to $6(54.5 \%)$ and sensitivity to $5(45.5 \%)$ of the antibiotics used. Thirteen $(86.7 \%)$ of the fifteen strains showed resistance to cefixime and ampicillin antibiotics each while recording the least sensitivity of $2(13.3 \%)$ each of them. This was followed by $11(73.3 \%)$ strains that recorded resistance to ceftazidime. Twelve $(80.0 \%)$ and $10(66.7 \%)$ strains recorded sensitivity to streptomycin and nitrofurantoin respectively. Only 2(13.3\%) strains showed sensitivity to cefixime and ampicillin followed by ceftazidime. The most sensitive antibiotics were streptomycin and nitrofurantoin (Table 1). 
IOSR Journal of Pharmacy

Vol. 2, Issue 3, May-June, 2012, PP.540-568

Table 1: Susceptibility patterns of antibiotics used on Escherichia coli uropathogenic strains $\left(\mathrm{EC}_{1}-\mathrm{EC}_{15}\right)$ after incubation at $37^{\circ} \mathrm{C}$ for 24 hours.

\begin{tabular}{|c|c|c|c|c|c|c|c|c|c|c|c|c|c|}
\hline \multirow{3}{*}{$\begin{array}{l}\text { E.coli } \\
\text { STRAIN } \\
\text { Codes }\end{array}$} & \multirow[b]{3}{*}{ NIT } & \multirow[b]{3}{*}{$\mathrm{CPR}$} & \multirow[b]{3}{*}{ CAZ } & \multirow{2}{*}{\multicolumn{4}{|c|}{ ANTIBIOTIC REACTIONS }} & \multirow[b]{3}{*}{ AUG } & \multirow[b]{3}{*}{ PEF } & \multirow[b]{3}{*}{ PN } & \multirow{3}{*}{\multicolumn{2}{|c|}{$\begin{array}{l}\% \\
\text { SENS }\end{array}$}} & \multirow{3}{*}{$\begin{array}{l}\% \\
\text { RESIST }\end{array}$} \\
\hline & & & & & & & & & & & & & \\
\hline & & & & NA & GEN & CXM & OFL & & & & & & \\
\hline $\mathrm{EC}_{1}$ & $\mathrm{~S}$ & $\mathrm{R}$ & $\mathrm{R}$ & $\mathrm{R}$ & $\mathrm{S}$ & $\mathrm{R}$ & $\mathrm{R}$ & $\mathrm{R}$ & $S$ & $\mathrm{R}$ & S & $4(36.4)$ & $7(63.6)$ \\
\hline $\mathrm{EC}_{2}$ & S & $\mathrm{R}$ & $\mathrm{R}$ & $\mathrm{S}$ & $S$ & $\mathrm{R}$ & $\mathrm{R}$ & $\mathrm{R}$ & $\mathrm{R}$ & $\mathrm{R}$ & $\mathrm{S}$ & $3(27.3)$ & $8(72.7)$ \\
\hline $\mathrm{EC}_{3}$ & $S$ & S & $\mathrm{R}$ & $\mathrm{R}$ & $S$ & $\mathrm{R}$ & $S$ & $\mathrm{R}$ & $\mathrm{R}$ & $\mathrm{R}$ & $\mathrm{R}$ & $4(36.4)$ & $7(63.6)$ \\
\hline $\mathrm{EC}_{4}$ & $\mathrm{R}$ & S & $\mathrm{R}$ & $\mathrm{R}$ & $S$ & $\mathrm{~S}$ & $S$ & $S$ & $\mathrm{R}$ & $\mathrm{R}$ & $\mathrm{R}$ & $5(45.5)$ & $6(54.5)$ \\
\hline $\mathrm{EC}_{5}$ & $S$ & $\mathrm{R}$ & $\mathrm{R}$ & $\mathrm{R}$ & $\mathrm{R}$ & $\mathrm{R}$ & $\mathrm{R}$ & $\mathrm{R}$ & $\mathrm{R}$ & $\mathrm{R}$ & S & $2(18.2)$ & $9(81.8)$ \\
\hline $\mathrm{EC}_{6}$ & $\mathrm{R}$ & $\mathrm{R}$ & $\mathrm{R}$ & $S$ & $S$ & $\mathrm{R}$ & $\mathrm{R}$ & $\mathrm{R}$ & $S$ & $\mathrm{R}$ & S & $4(36.4)$ & $7(63.6)$ \\
\hline $\mathrm{EC}_{7}$ & $\mathrm{~S}$ & S & $\mathrm{S}$ & S & $\mathrm{S}$ & $\mathrm{R}$ & $S$ & $\mathrm{~S}$ & S & $\mathrm{R}$ & S & $9(81.8)$ & $2(18.2)$ \\
\hline $\mathrm{EC}_{8}$ & S & $S$ & $\mathrm{R}$ & $S$ & $\mathrm{R}$ & $\mathrm{R}$ & $\mathrm{R}$ & $\mathrm{R}$ & $S$ & $\mathrm{R}$ & $S$ & $5(45.5)$ & $6(54.5)$ \\
\hline $\mathrm{EC}_{9}$ & $\mathrm{R}$ & $S$ & $\mathrm{~S}$ & $\mathrm{~S}$ & $S$ & $\mathrm{R}$ & S & $S$ & $\mathrm{~S}$ & $S$ & $S$ & $9(81.8)$ & $2(18.2)$ \\
\hline $\mathrm{EC}_{10}$ & $S$ & $S$ & $\mathrm{~S}$ & $S$ & $S$ & S & S & S & $\mathrm{S}$ & $\mathrm{R}$ & S & $10(90.9)$ & $1(9.1)$ \\
\hline $\mathrm{EC}_{11}$ & $\mathrm{R}$ & $\mathrm{R}$ & $\mathrm{R}$ & $\mathrm{S}$ & $\mathrm{R}$ & $\mathrm{R}$ & $\mathrm{R}$ & $\mathrm{R}$ & $\mathrm{R}$ & $\mathrm{R}$ & S & $2(18.2)$ & $9(81.8)$ \\
\hline $\mathrm{EC}_{12}$ & $S$ & $\mathrm{R}$ & $\mathrm{R}$ & $\mathrm{R}$ & $\mathrm{R}$ & $\mathrm{R}$ & $\mathrm{R}$ & $\mathrm{R}$ & $S$ & $\mathrm{R}$ & $S$ & $3(27.3)$ & $8(72.7)$ \\
\hline $\mathrm{EC}_{13}$ & $S$ & $S$ & $\mathrm{R}$ & $\mathrm{S}$ & $\mathrm{R}$ & $\mathrm{R}$ & $\mathrm{R}$ & $\mathrm{R}$ & $S$ & $\mathrm{R}$ & $\mathrm{R}$ & $4(36.4)$ & $7(63.6)$ \\
\hline $\mathrm{EC}_{14}$ & $S$ & $S$ & $\mathrm{~S}$ & $S$ & $\mathrm{R}$ & $\mathrm{R}$ & $S$ & $S$ & $S$ & $S$ & $S$ & $9(81.8)$ & $2(18.2)$ \\
\hline $\mathrm{EC}_{15}$ & $\mathrm{R}$ & $S$ & $\mathrm{R}$ & $\mathrm{R}$ & $\mathrm{R}$ & $\mathrm{R}$ & $S$ & $\mathrm{R}$ & $\mathrm{R}$ & $\mathrm{R}$ & $S$ & $3(27.3)$ & $8(72.7)$ \\
\hline $\begin{array}{c}\text { TOTAL } \\
\% \\
\text { SENS. }\end{array}$ & $\begin{array}{l}10 \\
(66.7)\end{array}$ & $\begin{array}{l}9 \\
(60.0)\end{array}$ & $\begin{array}{l}4 \\
(22.7)\end{array}$ & $\begin{array}{l}9 \\
(60.0)\end{array}$ & $\begin{array}{l}8 \\
(53.3)\end{array}$ & $\begin{array}{l}2 \\
(13.3)\end{array}$ & $\begin{array}{l}6 \\
(30.0)\end{array}$ & $\begin{array}{l}5 \\
(33.3)\end{array}$ & $\begin{array}{l}9 \\
(60.0)\end{array}$ & $\begin{array}{l}2 \\
(13.3)\end{array}$ & $\begin{array}{l}12 \\
(80.0)\end{array}$ & & \\
\hline $\begin{array}{c}\text { TOTAL } \\
\% \\
\text { RESIST. }\end{array}$ & $\begin{array}{l}5 \\
(33.3)\end{array}$ & $\begin{array}{l}6 \\
(30.0)\end{array}$ & $\begin{array}{l}11 \\
(73.3)\end{array}$ & $\begin{array}{l}6 \\
(30.0)\end{array}$ & $\begin{array}{l}7 \\
(46.7)\end{array}$ & $\begin{array}{l}13 \\
(86.7\end{array}$ & $\begin{array}{l}9 \\
(60.0)\end{array}$ & $\begin{array}{l}10 \\
(66.7)\end{array}$ & $\begin{array}{l}6 \\
(30.0)\end{array}$ & $\begin{array}{l}13 \\
(86.7\end{array}$ & $\begin{array}{c}3 \\
(20.0)\end{array}$ & & \\
\hline
\end{tabular}

The antibiotic sensitivity reactions of pure $\mathrm{EC}_{8}$ strain before exposure to Homodium bromide and after incubation for 24hours are shown in Table 2. Out of the antibiotics tested, the pathogen resisted $8(72.8 \%)$ completely. The isolate was sensitive to the remaining $3(27.2 \%)$ of the tested antimicrobial agents which included gentamicin, nitrofurantoin and streptomycin. The resisted drugs included ofloxacin, augmentin, ceftazidime, cefixime, ciprofloxacin, pefloxacin, nalidixic acid and ampicillin. Mean zones of inhibition recorded for the three sensitive antibiotics after 6hours, 12hours, 18 hours and 24 hours incubation before treatment with the agent were $0.73 \mathrm{~mm}, 0.87 \mathrm{~mm}, 1.53 \mathrm{~mm}$ and 2.07 mmrespectively(Table 
Table 2: Susceptibility pattern of multidrug resistant $\mathrm{EC}_{8}$ strain before treatment with Homodium bromide after incubation at $37^{\circ} \mathrm{C}$ for 24 hours.

\begin{tabular}{ccccccccccccc}
\hline $\begin{array}{c}\text { Incubation } \\
\text { Time(Hrs) }\end{array}$ & NIT & CPR & CAZ & NA & GEN & CXM & OFL & AUG & PEF & PN & ST & Mean \\
\hline 6 & 1.0 & $\mathrm{R}$ & $\mathrm{R}$ & $\mathrm{R}$ & 0.8 & $\mathrm{R}$ & $\mathrm{R}$ & $\mathrm{R}$ & $\mathrm{R}$ & $\mathrm{R}$ & 0.4 & $0.73 \mathrm{~mm}$ \\
12 & 1.6 & $\mathrm{R}$ & $\mathrm{R}$ & $\mathrm{R}$ & 1.2 & $\mathrm{R}$ & $\mathrm{R}$ & $\mathrm{R}$ & $\mathrm{R}$ & $\mathrm{R}$ & 0.7 & $0.87 \mathrm{~mm}$ \\
18 & 2.2 & $\mathrm{R}$ & $\mathrm{R}$ & $\mathrm{R}$ & 1.4 & $\mathrm{R}$ & $\mathrm{R}$ & $\mathrm{R}$ & $\mathrm{R}$ & $\mathrm{R}$ & 1.0 & $1.5 \mathrm{~mm}$ \\
24 & 6.0 & $\mathrm{R}$ & $\mathrm{R}$ & $\mathrm{R}$ & 1.8 & $\mathrm{R}$ & $\mathrm{R}$ & $\mathrm{R}$ & $\mathrm{R}$ & $\mathrm{R}$ & 1.4 & $2.07 \mathrm{~mm}$ \\
\hline Mean & $\mathbf{2 . 7 0 m m}$ & & & & $\mathbf{1 . 3 m m}$ & & & & & & & \\
\hline
\end{tabular}

$\mathrm{NIT}=$ Nitrofurantoin,$\quad \mathrm{AUG}=$ Augmentin,$\quad \mathrm{CPR}=$ Ciprofloxacin,$\quad \mathrm{PEF}=$ Pefloxacin, $\mathrm{CAZ}=$ Ceftazidime,$\quad \mathrm{PN}=$ Ampicillin $\mathrm{NA}=$ Nalidixic Acid,$\quad \mathrm{ST}=$ Streptomycin, $\mathrm{GEN}=$ Gentamicin, $\mathrm{CXM}=$ Cefixime, $\mathrm{OFL}=$ Ofloxacin 
Following treatment with non-toxic laboratory doses (dilutions) of homodium bromide and incubation for 6hours at $37^{\circ} \mathrm{C}$, there was enhanced antibiotic susceptibility (increased zones of inhibition) of the $\mathrm{EC}_{8}$ strain to gentamicin, nitrofurantoin and streptomycin. The remaining antibiotics as listed above did not show any change in reaction at all. A paired t-test analysis at $95 \%$ confidence interval showed that homodium bromide dilutions of $0.35,0.45 .0 .85$ and $0.95 \mathrm{ug} / \mathrm{ml}$ influenced significant sensitivity enhancements of $2.83 \pm 1.58 \mathrm{~mm}, 1.40 \pm 0.86 \mathrm{~mm}, 2.53 \pm 0.29 \mathrm{~mm}$ and $1.20 \pm 0.50 \mathrm{~mm}$ respectively $(\mathrm{P}<0.05)$ with calculated t-values of 7.727, 7.000, 37.93 and 10.39 respectively. These values were compared with a p-value at 2 degree of freedom of 4.303 . Only $2.53 \pm 0.29 \mathrm{~mm}$ and $1.20 \pm 0.50 \mathrm{~mm}$ zones of inhibition produced however by 0.85 and $0.95 \mathrm{ug} / \mathrm{ml}$ concentrations were highly significant at $99 \%$ confidence interval (P<0.01) Table 3. 
Table 3: Susceptibility patterns of multidrug resistant $\mathrm{EC}_{8}$ strain to three antimicrobial agents after invitro treatment with non-toxic laboratory concentrations of homodium bromide and incubation for 6 hours at $37^{\circ} \mathrm{C}$

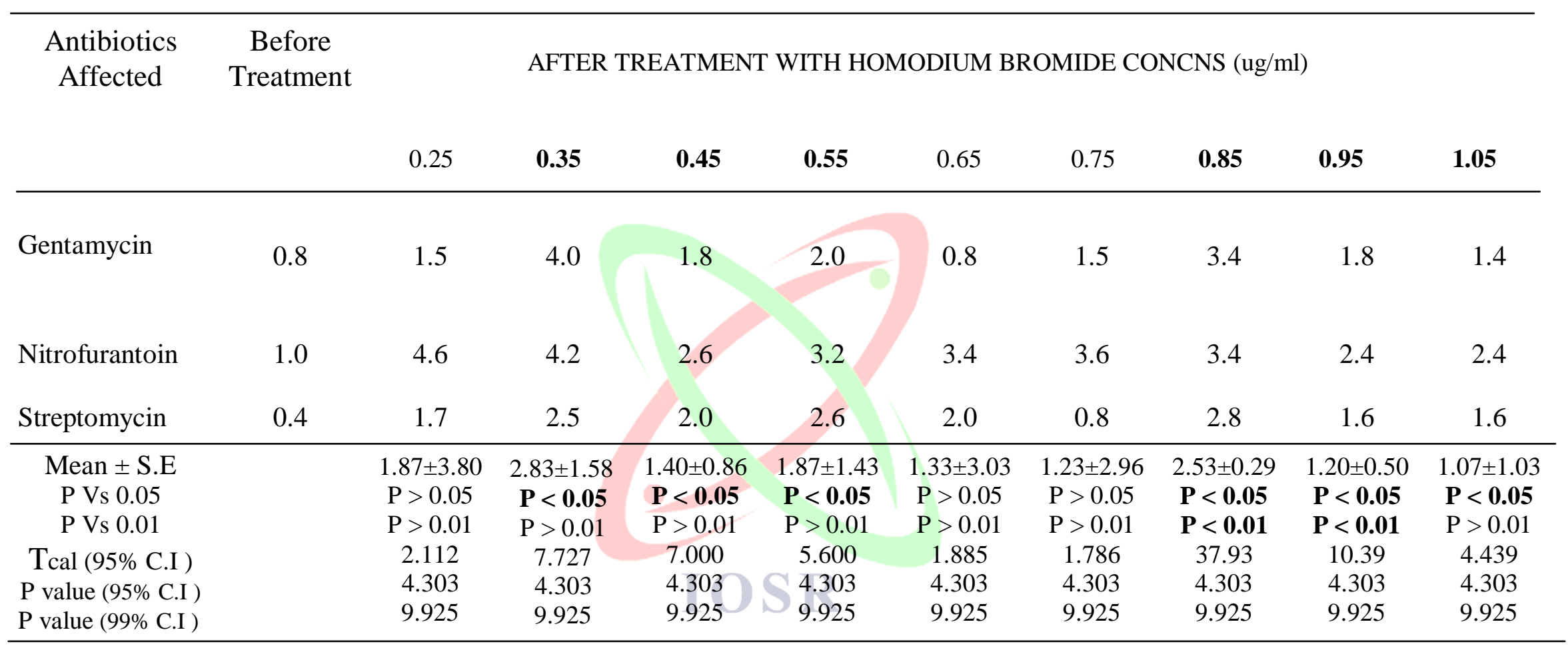

NOTE: 1 Statistical pairings of Zones of inhibition after treatment were done with those before treatment $(0.8,1.0 \& 0.4 \mathrm{~mm}$ which are constant)

2. Concentrations of Homodium bromide highlighted represent dilutions that produced significant sensitization enhancements. 
After 12hours incubation after treatment, $0.35,0.45,0.85$ and $0.95 \mathrm{ug} / \mathrm{ml}$ homodium bromide dilutions produced significant sensitization enhancement of $2.67 \pm 1.43 \mathrm{~mm}, 1.00 \pm 0.99 \mathrm{~mm}, 2.10 \pm 0.66 \mathrm{~mm}$ and $0.80 \pm 0.25 \mathrm{~mm}$ respectively $(\mathrm{P}<0.05)$ each having $\mathrm{t}$-cal values of $8.01,4.330,13.748$ and 13.857 respectively. Only $0.85 \mathrm{ug} / \mathrm{ml}$ and $0.95 \mathrm{ug} / \mathrm{ml}$ dilutions however, were highly significant at $99 \%$ confidence limit $(\mathrm{P}<0.01)$ Table 4. 
Table 4: Susceptibility patterns of multidrug resistant $\mathrm{EC}_{8}$ strain to three antimicrobial agents after invitro treatment with non-toxic laboratory concentrations of homodium bromide and incubation for $\mathbf{1 2 h o u r s ~ a t ~} 37^{\circ} \mathrm{C}$

\begin{tabular}{|c|c|c|c|c|c|c|c|c|c|c|}
\hline \multirow[t]{2}{*}{$\begin{array}{c}\text { Antibiotics } \\
\text { Affected }\end{array}$} & \multirow[t]{2}{*}{$\begin{array}{c}\text { Before } \\
\text { Treatment }\end{array}$} & \multicolumn{9}{|c|}{ AFTER TREATMENT WITH HOMODIUM BROMIDE CONCNS (ug/ml) } \\
\hline & & 0.25 & 0.35 & 0.45 & 0.55 & 0.65 & 0.75 & 0.85 & 0.95 & 1.05 \\
\hline Gentamycin & 1.2 & 1.7 & 4.2 & 1.8 & 2.0 & 0.9 & 1.5 & 3.4 & 1.9 & 1.4 \\
\hline Nitrofurantoin & 1.6 & 4.6 & 4.6 & 2.6 & 3.4 & 3.6 & 3.6 & 3.4 & 2.4 & 2.8 \\
\hline Streptomycin & 0.7 & 1.8 & 2.7 & 2.1 & 2.6 & 2.0 & 0.8 & 3.0 & 1.6 & 1.6 \\
\hline Mean \pm S.E & & $1.53 \pm 3.24$ & $2.67 \pm 1.43$ & $1.00 \pm 0.99$ & $1.50 \pm 1.51$ & $1.00 \pm 2.93$ & $0.80 \pm 2.59$ & $2.10 \pm 0.66$ & $0.80 \pm 0.25$ & $0.77 \pm 1.28$ \\
\hline P Vs 0.05 & & $\mathrm{P}>0.05$ & $P<0.05$ & $\mathbf{P}<\mathbf{0 . 0 5}$ & $\mathrm{P}>0.05$ & $\mathrm{P}>0.05$ & $\mathrm{P}>0.05$ & $P<0.05$ & $P<0.05$ & $\mathrm{P}>0.05$ \\
\hline P Vs 0.01 & & $\mathrm{P}>0.01$ & $\mathrm{P}>0.01$ & $\mathrm{P}>0.01$ & $P>0.01$ & $\mathrm{P}>0.01$ & $\mathrm{P}>0.01$ & $P<0.01$ & $P<0.01$ & $\mathrm{P}>0.01$ \\
\hline Tcal (95\% C.I ) & & 2.030 & 8.010 & 4.330 & 4.271 & 1.470 & 1.327 & 13.748 & 2.599 & 13.857 \\
\hline $\mathrm{P}$ value (95\% C.I ) & & 4.303 & 4.303 & 4.303 & 4.303 & 4.303 & 4.303 & 4.303 & 4.303 & 4.303 \\
\hline P value (99\% C.I ) & & 9.925 & 9.925 & 9.925 & 9.925 & 9.925 & 9.925 & 9.925 & 9.925 & 9.925 \\
\hline
\end{tabular}

NOTE: 1 . Statistical pairings of Zones of inhibition after treatment were done with those before treatment $(1.2,1.6$ and $0.7 \mathrm{~mm}$ which are constant)

2. Concentrations of Homodium bromide highlighted represent dilutions that produced significant sensitization enhancements 
Eighteen hours incubation of multidrug resistant $\mathrm{EC}_{8}$ strain after treatment with $0.35,0.45$ and $0.85 \mathrm{ug} / \mathrm{ml}$ concentrations of homodium bromide produced significant zones of inhibition improvement of $2.50 \pm 1.74 \mathrm{~mm}, 1.73 \pm 1.25 \mathrm{~mm}$ and $1.87 \pm 1.43 \mathrm{~mm}$ respectively at $95 \%$ confidence interval $(\mathrm{P}<0.05)$ with t-cal values of 6.186, 5.953 and 5.610 respectively. None of these was however significant at $99 \%$ $(\mathrm{P}>0.01)$ Table 5. 
Table 5: Susceptibility patterns of multidrug resistant $\mathrm{EC}_{8}$ strain to three antimicrobial agents after invitro treatment with non-toxic laboratory concentrations of homodium bromide and incubation for 18 hours at $37^{\circ} \mathrm{C}$

\begin{tabular}{|c|c|c|c|c|c|c|c|c|c|c|}
\hline \multirow{2}{*}{$\begin{array}{c}\text { Antibiotics } \\
\text { Affected }\end{array}$} & \multirow{2}{*}{$\begin{array}{c}\text { Before } \\
\text { Treatment }\end{array}$} & \multicolumn{9}{|c|}{ AFTER TREATMENT WITH HOMODIUM BROMIDE CONCNS (ug/ml) } \\
\hline & & 0.25 & 0.35 & 0.45 & 0.55 & 0.65 & 0.75 & 0.85 & 0.95 & $1.05(\mathrm{ug} / \mathrm{ml})$ \\
\hline Gentamycin & 1.4 & 2.0 & 4.6 & 1.8 & 3.2 & 1.0 & 1.5 & 3.6 & 1.9 & 1.4 \\
\hline Nitrofurantoin & 2.2 & 4.6 & 4.7 & 2.9 & 3.4 & 3.6 & 3.6 & 3.4 & & 2.8 \\
\hline Streptomycin & 1.0 & 2.0 & 2.8 & 2.8 & 3.2 & 2.0 & 0.8 & 3.2 & 1.6 & 1.6 \\
\hline Mean \pm S.E & & $1.33 \pm 2.35$ & $2.50 \pm 1.74$ & $1.97 \pm 2.32$ & $1.73 \pm 1.25$ & $0.67 \pm 2.35$ & $0.43 \pm 2.11$ & $1.87 \pm 1.43$ & $0.90 \pm 1.51$ & $0.40 \pm 0.86$ \\
\hline P Vs 0.05 & & $\mathrm{P}>0.05$ & $P<0.05$ & $\mathrm{P}>0.05$ & $P<0.05$ & $\mathrm{P}>0.05$ & $\mathrm{P}>0.05$ & $P<0.05$ & $\mathrm{P}>0.05$ & $\mathrm{P}>0.05$ \\
\hline P Vs 0.01 & & $\mathrm{P}>0.01$ & $\mathrm{P}>0.01$ & $P>0.01$ & $P>0.01$ & $P>0.01$ & $\mathrm{P}>0.01$ & $P>0.01$ & $\mathrm{P}>0.01$ & $\mathrm{P}>0.01$ \\
\hline Tcal (95\% C.I ) & & 2.437 & 6.186 & 1.800 & 5.953 & 1.228 & 0.876 & 5.610 & 2.563 & 2.000 \\
\hline $\mathrm{P}$ value (95\% C.I ) & & 4.303 & 4.303 & 4.303 & 4.303 & 4.303 & 4.303 & 4.303 & 4.303 & 4.303 \\
\hline P value (99\% C.I ) & & 9.925 & 9.925 & 9.925 & 9.925 & 9.925 & 9.925 & 9.925 & 9.925 & 9.925 \\
\hline
\end{tabular}

NOTE: 1.Statistical pairings of Zones of inhibition after treatment were done with those before treatment $(1.4,2.2 \mathrm{and} 1.0 \mathrm{~mm}$ which are constant)

2. Concentrations of Homodium bromide highlighted represent dilutions that produced significant sensitization enhancements 
Finally, incubation for 24hours after treatment, produced significant sensitivity enhancement of $2.40 \pm 1.49 \mathrm{~mm}(\mathrm{P}<0.05)$ at $0.35 \mathrm{ug} / \mathrm{ml}$ dilution only with $\mathrm{t}$-cal value of 6.928 . This was however highly insignificant at $99 \%$ confidence limit $(\mathrm{P}>0.01)$. Changes in zones of inhibition at the other concentrations of homodium bromide were not significant $(\mathrm{P}>0.05)$ and highly insignificant $(\mathrm{P}>0.01)$ at both $95 \%$ and $99 \%$ confidence limits (Table 6). 
IOSR Journal of Pharmacy

Vol. 2, Issue 3, May-June, 2012, PP.540-568

Table 6: Susceptibility patterns of multidrug resistant $\mathrm{EC}_{8}$ strain to three antimicrobial agents after invitro treatment with non-toxic laboratory concentrations of homodium bromide and incubation for 24 hours at $37^{\circ} \mathrm{C}$

\begin{tabular}{|c|c|c|c|c|c|c|c|c|c|c|}
\hline \multirow{2}{*}{$\begin{array}{l}\text { Antibiotics } \\
\text { Affected }\end{array}$} & \multirow{2}{*}{$\begin{array}{c}\text { Before } \\
\text { Treatment }\end{array}$} & \multicolumn{9}{|c|}{ AFTER TREATMENT WITH HOMODIUM BROMIDE CONCNS (ug/ml) } \\
\hline & & 0.25 & $\mathbf{0 . 3 5}$ & 0.45 & 0.55 & 0.65 & 0.75 & 0.85 & 0.95 & 1.05 \\
\hline Gentamycin & 1.8 & 2.1 & 4.8 & 2.2 & 3.2 & 1.0 & 1.5 & 3.6 & 3.8 & 2.0 \\
\hline Nitrofurantoin & 3.0 & 4.6 & 4.8 & 3.0 & 3.6 & 3.6 & 4.4 & 3.4 & 4.6 & 3.2 \\
\hline Streptomycin & 1.4 & 5.0 & 3.8 & 2.8 & 3.4 & 2.0 & 0.8 & 3.6 & 1.6 & 2.2 \\
\hline Septrin & 0.0 & 1.8 & 0.0 & 0.0 & 0.0 & 0.0 & 0.0 & 0.0 & 3.2 & 0.0 \\
\hline Ciprofloxacin & 0.0 & 0.0 & 0.0 & 0.0 & 0.0 & 0.0 & 0.0 & 0.0 & 3.0 & 0.0 \\
\hline Ceporex & 0.0 & 0.0 & 0.0 & 0.0 & 0.0 & 0.0 & 0.0 & 0.0 & 2.0 & 0.0 \\
\hline Pefloxacin & 0.0 & 0.0 & 0.0 & 0.0 & 0.0 & 0.0 & 0.0 & 0.0 & 4.2 & 0.0 \\
\hline Mean \pm S.E & & $1.83 \pm 4.13$ & $2.40 \pm 1.49$ & $0.60 \pm 1.79$ & $1.33 \pm 1.75$ & $0.13 \pm 2.01$ & $0.17 \pm 2.68$ & $1.47 \pm 2.35$ & $1.27 \pm 2.35$ & $0.40 \pm 0.86$ \\
\hline P Vs 0.05 & & $\mathrm{P}>0.05$ & $\mathrm{P}<0.05$ & $\mathrm{P}>0.05$ & $\mathrm{P}>0.05$ & $\mathrm{P}>0.05$ & $\mathrm{P}>0.05$ & $\mathrm{P}>0.05$ & $\mathrm{P}>0.05$ & $\mathrm{P}>0.05$ \\
\hline P Vs 0.01 & & $\mathrm{P}>0.01$ & $\mathrm{P}>0.01$ & $\mathrm{P}>0.01$ & $\mathrm{P}>0.01$ & $\mathrm{P}>0.01$ & $\mathrm{P}>0.01$ & $\mathrm{P}>0.01$ & $\mathrm{P}>0.01$ & $\mathrm{P}>0.01$ \\
\hline Tcal (95\% C.I ) & & 1.907 & 6.928 & 1.441 & 3.280 & 0.285 & 0.876 & 2.694 & 2.322 & 2.000 \\
\hline $\mathrm{P}$ value $(95 \%$ C.I $)$ & & 4.303 & 4.303 & 4.303 & 4.303 & 4.303 & 4.303 & 4.303 & 4.303 & 4.303 \\
\hline P value (99\% C.I ) & & 9.925 & 9.925 & 9.925 & 9.925 & 9.925 & 9.925 & 9.925 & 9.925 & 9.925 \\
\hline
\end{tabular}


Presented in Table 7, is the effect of the concentrations of homodium bromide on the minimum inhibitory concentration of gentamicin as it inhibited the growth of multidrug resistant $\mathrm{EC}_{8}$ strain after treatment. Whereas homodium bromide dilutions of $0.25,0.55,0.65$ and $1.05 \mathrm{ug} / \mathrm{ml}$ yielded no change (i.e reduction) in minimum inhibitory concentration (MIC), $0.35 \mathrm{ug} / \mathrm{ml}$ homodium bromide dose reduced gentamicin MIC from 10ug to 2.5ug (four fold reduction). A two-fold reduction in MIC was recorded after treatment with $0.45 \mathrm{ug} / \mathrm{ml}$ dilution of the agent. Other dilutions (i.e $0.75,0.85$ and $0.95 \mathrm{ug} / \mathrm{ml}$ ) produced two-fold $(5 \mathrm{ug})$, four-fold $(2.5 \mathrm{ug})$ and four-fold (2.5ug) MIC reductions of gentamicin respectively (Table 7). 
Table 7: Homodium bromide dilutions effect on the Minimum Inhibitory Concentration (MIC) of gentamicin on multidrug resistant $\mathrm{EC}_{8}$ strain after 24 hours incubation at $37^{\circ} \mathrm{C}$.

\begin{tabular}{|c|c|c|c|c|c|c|c|c|c|c|c|c|c|}
\hline \multirow{2}{*}{$\begin{array}{l}\text { Non toxic } \\
\text { homodium } \\
\text { bromide } \\
\text { dilutions } \\
\text { used(ug/ml) }\end{array}$} & \multirow{2}{*}{$\begin{array}{l}\text { New } \\
\text { MIC } \\
\text { after } \\
\text { Tmt } \\
\text { (ug) }\end{array}$} & \multicolumn{12}{|c|}{ Serial Dilutions of Gentamicin MIC (10ug) } \\
\hline & & 10.0 & 5.0 & 2.5 & 1.25 & 0.63 & 0.32 & 0.16 & 0.08 & 0.04 & $\begin{array}{l}\text { Inoculum } \\
\text { Control }\end{array}$ & $\begin{array}{l}\text { Broth } \\
\text { Control }\end{array}$ & $\begin{array}{l}\text { Drug } \\
\text { Control }\end{array}$ \\
\hline 0.25 & $\begin{array}{c}\text { No } \\
\text { change }\end{array}$ & - & + & + & + & + & + & + & + & + & - & - & - \\
\hline 0.35 & 2.5 & - & - & - & + & & & + & + & + & - & - & - \\
\hline 0.45 & 5.0 & - & - & + & + & + & + & + & + & + & - & - & - \\
\hline 0.55 & $\begin{array}{c}\text { No } \\
\text { change }\end{array}$ & - & + & + & + & + & + & + & + & + & - & - & - \\
\hline 0.65 & $\begin{array}{c}\text { No } \\
\text { change }\end{array}$ & - & + & + & + & + & + & + & + & + & - & - & - \\
\hline 0.75 & 5.0 & - & - & + & + & + & + & + & + & + & - & - & - \\
\hline 0.85 & 2.5 & - & - & - & + & + & + & + & + & + & - & - & - \\
\hline 0.95 & 2.5 & - & - & - & + & + & + & + & + & + & - & - & - \\
\hline 1.05 & $\begin{array}{c}\text { No } \\
\text { change }\end{array}$ & - & + & + & + & + & + & + & + & + & - & - & - \\
\hline
\end{tabular}


In Table 8, is presented mean percentage sensitization enhancements of antibiotics to which multidrug resistant $\mathrm{EC}_{8}$ strain showed sensitivity before and after treatment with homodium bromide. Mean percentage enhancements recorded for gentamicin, nitrofurantoin and streptomycin after 6, 12, 18 and 24hours incubation after treatment were $171.7 \%, 138.9 \%, 57.4 \%$ and $50.8 \%$ respectively. Mean percentage sensitivity enhancement of $\mathrm{MDR} \mathrm{EC}_{8}$ strain to gentamicin was $50.9 \%$. It was $109.2 \%$ and $153.9 \%$ to nitrofurantoin and streptomycin respectively. A liitle over $50.0 \%$ mean percentage sensitivity enhancement of $\mathrm{EC}_{8}$ strain to gentamicin was recorded while over $100.0 \%$ enhancements were recorded for nitrofurantoin and streptomycin each (Table 8) 
Table 8: Mean Percentage Sensitization Enhancement of drugs to which $\mathrm{EC}_{8}$ strain showed susceptibility before and after treatment with homodium bromide

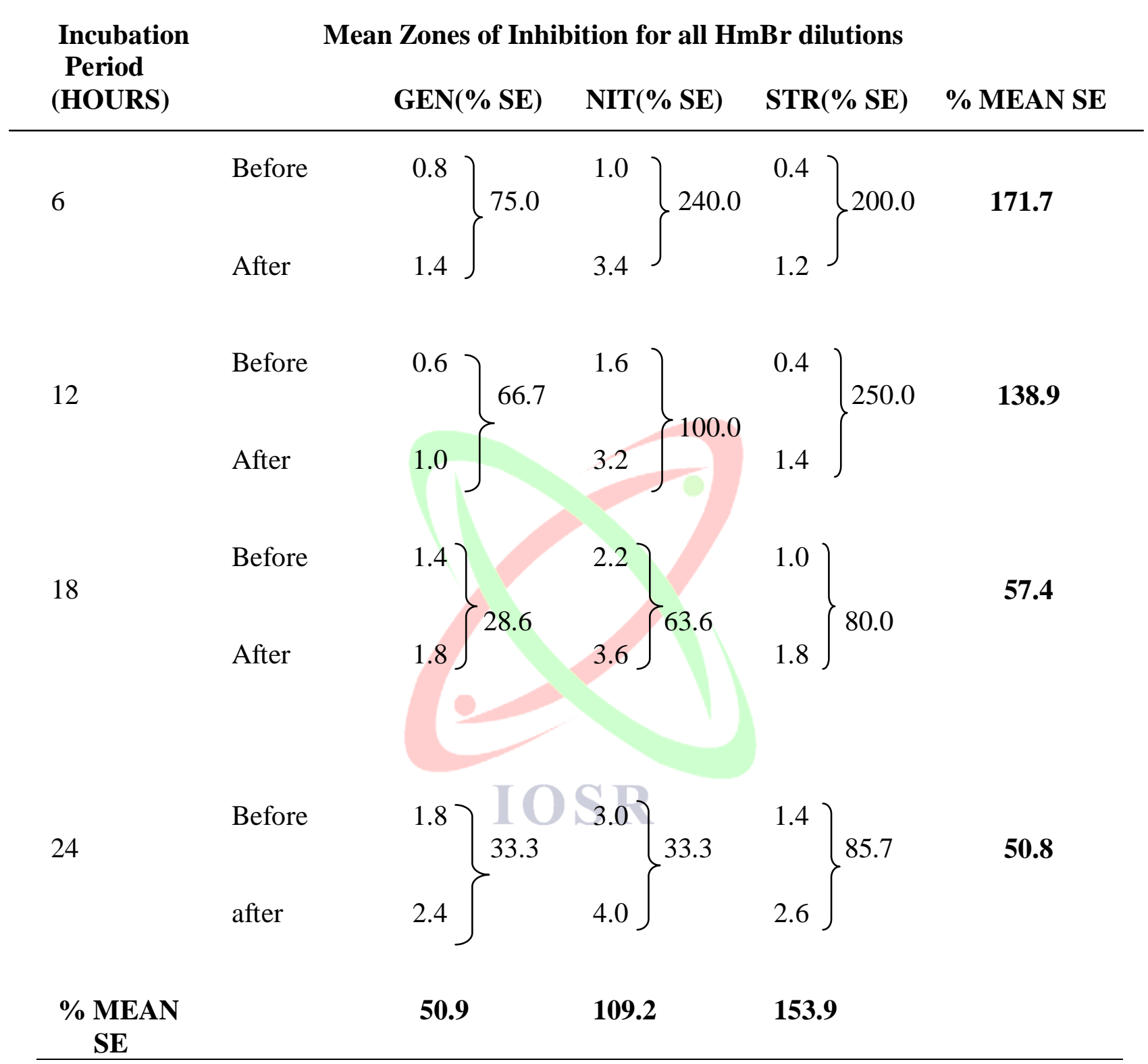

$\mathrm{SE}=$ Sensitization enhancement MDR $\mathrm{EC}_{8}=$ Multidrug resistant Escherichia coli strain 8 Zones of inhibition at 6,12,18 and 24hours of incubation after treatment are mean values for all dilutions of $\mathrm{HmBr}$. 


\section{DISCUSSION}

Antibiotic resistance to beta lactams, macrolides, quinolones and tetracyclines is an increasing problem in many countries (Baquero et al., 1999; Li and Nikaido, 2004). Also, the lack of new antibacterial agents has provoked considerable interests in restoring the activities of older antibiotics (Piddock, 2006). One way of restoring the activities of older antibiotics is to inhibit the action of efflux pumps and thus enhance permeability of antibiotics unto the bacterial cells through the membranes (Lomovskaya and Bostian, 2006).

Byron et al. (2003) tested the ability of sesquiterpenoids (i.e nerolidol, bisabolol and apritone) and ethidium bromide (also known as homodium bromide) to enhance Staphylococcus aureus (ATCC 6538) susceptibility to low molecular weight compounds especially antibiotics such as ciprofloxacin, clindamycin, erythromycin, gentamycin, tetracycline and vancomycin. They reported that all agents enhanced the activities of all six antibiotics tested against Staph. aureus with gentamycin showing the largest relative increases in inhibition zone size for each agent tested.

Non - toxic laboratory dilutions $(0.35-1.05 \mathrm{ug} / \mathrm{ml})$ of homodium bromide (Wurmb-Schwark et al., 2006) was used to enhance the sensitivity of a multidrug resistant Escherichia coli male urinary tract pure isolate to three commonly used antibiotics which included gentamicin, nitrofurantoin and streptomycin. These antibiotics were the only three to which the isolate showed visible sensitivity out of eleven initially used before homodium bromide treatment (Table 1). Resistance of isolate to ciprofloxacin, pefloxacin and ofloxacin may be due to presence of plasmid genes which coded for extended beta lactamases (Paterson and Bonomo, 2005).

Isolate in this study was resistant to more than three antibiotics and hence, it is a multidrug resistant Escherichia coli strain (Jan et al., 2004). Multidrug resistance is now common in familiar pathogens such as Escherichia coli, Staphylococcus aureus and Klebsiella pneumoniae (Stavril et al., 2007). Besides, problems now exist with the prevalence of human pathogenic bacteria over expressing pumps and conferring multidrug resistance (Stavril et al., 2007)

Robertson et al. (2005) reported that inactivated efflux pump genes gave rise to hyper susceptibility of Streptococcus pneumoniae Rb to ciprofloxacin and norfloxacin after treatment with ethidium bromide and acriflavine. Ethidium bromide may affect the membrane potential, membrane permeability, protein synthesis/ processing of DNA as well as elimination of plasmids (Stanisich, 1984; Viljanen and Boratynski, 1991).

Eleven antibiotics namely nitrofurantoin,ciprofloxacin, ceftazidime, nalidixic acid, gentamicin, cefixime, ofloxacin, augmentin, pefloxacin, ampicillin and streptomycin were selected based on availability to users (patients) and cost (though not all are easily affordable) among the sampled population. After 6-24hours incubation, only three (27.2\%) of the antibiotics (namely nitrofurantoin, gentamicin and streptomycin) showed mean zones of inhibition of $2.70 \mathrm{~mm}, 1.3 \mathrm{~mm}$ and $0.88 \mathrm{~mm}$ respectively. More than $50 \%$ of the applied drugs were resisted by Escherichia coli. According to Jan et al. (2004), a multidrug resistant pathogen is one that is resistant to three or more antibiotics at a time.

The urinary tract isolate in this study is therefore a multidrug Escherichia coli organism of which its high resistant rate is supported by Cohen (1992) findings part of which stated that multiple antimicrobial resistances among gram negative organisms such as Escherichia coli, Klebsiella spp, Proteus spp to mention a few, have been a long term and well recognized problem with urinary tract infections. The mechanism by which these urinary tract pathogens resist antimicrobial agents range from intrinsic impermeability to acquired resistance involving plasmids, transposons and mutations (Gutmann, 1985). 
Production of extended spectrum beta-lactamase (ESBL) among E.coli and Klebsiella pneumoniae also contributed significantly to the resistance of these isolates (Jenks et al., 1995). There was steady and consistent increase in zones of inhibition with time of incubation. Hence, after 6, 12, 18 and 24hours of incubation, zones of inhibition recorded were $0.73 \mathrm{~mm}, 0.87 \mathrm{~mm}, 1.5 \mathrm{~mm}$ and $2.07 \mathrm{~mm}$ respectively. That the highest inhibition zone was attained after 24hours, may support the convention of "24hour incubation" for antibiotic invitro sensitivity studies.

After $0.25-1.05 \mathrm{ug} / \mathrm{ml}$ treatment of multidrug resistant Escherichia coli isolate and subsequent exposure to gentamicin, nitrofurantoin and streptomycin for 6hours, there was enhanced antibiotic susceptibility (increased zones of inhibition). Homodium bromide concentrations of 0.85 and $0.95 \mathrm{ug} / \mathrm{ml}$ produced highly significant $(\mathrm{P}<0.01)$ zones of inhibition of $2.53 \pm 0.29 \mathrm{~mm}$ and $1.20 \pm 0.50 \mathrm{~mm}$ respectively. Homodium bromide concentrations of $0.85 \mathrm{ug} / \mathrm{ml}$ and $0.95 \mathrm{ug} / \mathrm{ml}$ are non-toxic to the host bacterium (Wurmb-Schwark et al., 2006) and in this case, multidrug Escherichia coli. These concentrations are enough to cure antibiotic resistance plasmid genes of this pathogen and therefore, enhance its sensitivity to any or all of gentamicin, nitrofurantoin and streptomycin. The concentrations are also lower than doses that may inhibit or kill the host organisms. This finding is consistent with that of Trevors (1986) which established non-toxic concentrations of comermycin, rifampicin and novobiocin as curing agents which inhibited DNA gyrase/RNA polymerase thus promoting effective elimination of plasmids. The concentrations $(50-200 \mathrm{ug} / \mathrm{ml})$ of epigallocatechin gallate ( a tea catechin) used as a curing compound on E.coli strains by Zhao et al. (2001) are at variance with the finding in this study as they appear very high.

Sub-inhibitory dilutions of 0.85 and $0.95 \mathrm{ug} / \mathrm{ml}$ enhanced sensitivity of all three drugs after 6hours incubation when compared to their sensitivity before treatment with homodium bromide in line with a report which states that DNA intercalating dyes such as homodium bromide (ethidium bromide) and others have a very successful effect on sensitization of previously resistant bacteria (Chakrabartty et al., 1984; Gupta et al., 1980; Obaseki-Ebor, 1984; Reddy et al., 1986). Ethidium bromide (homodium bromide) is a model efflux substrate that the only known mechanism of resistance is through efflux (Mullin et al., 2004).

Some curing compounds block plasmid transfer and such inhibition is dose (concentration) dependent (Zhao et al., 2001) and the most effective concentrations of a curing agent depend upon the species being treated, efficiency of the curing agent and the mode of action of that particular compound (Carlton and Brown, 1981). Hence, homodium bromide concentrations of 0.85 and $0.95 \mathrm{ug} / \mathrm{ml}$ (or their average) appear to be excellent for increased (enhanced) sensitization of multidrug Escherichia coli when applied for 6hours. The various researched curing agents may have several different modes of action. They may affect membrane potential, membrane permeability, protein synthesis, processing of DNA and eliminating certain types of plasmids (Stanisich, 1984; Viljanen and Boratynski, 1991).

The same sub-inhibitory doses of 0.85 and $0.95 \mathrm{ug} / \mathrm{ml}$ of homodium bromide were significant $(\mathrm{P}<0.05)$ and highly significant $(\mathrm{P}<0.01)$ in enhancing MDR E.coli sensitivity to the three antibiotics after 12hours incubation (Table 3). Though 0.35 and $0.45 \mathrm{ug} / \mathrm{ml}$ concentrations were significant sensitivity enhancers $(P<0.05)$ but were not highly significant $(P>0.01)$ enhancers. The most effective concentrations of a curing agent depend on the species being treated, efficiency of the curing agent and the mode of action of the agent (Carlton and Brown, 1981). Escherichia coli by virtue of being piliated and a frequent member of biofilms (where many species of bacteria exist in close proximity to each other), it is able to accept and transfer plasmids from and to other bacteria (Perfeito et al., 2007). This therefore makes E.coli a good candidate for plasmid curing and sensitivity enhancement in the event of becoming (which is the case most times), a multidrug resistant strain. 
After 18 hours incubation, $0.35,0.55$ and $0.85 \mathrm{ug} / \mathrm{ml}$ concentrations were significant $(\mathrm{P}<0.05)$ sensitivity enhancers. They were however not highly significant in enhancing sensitivity of MDR EC 8 strain to nitrofurantoin, gentamicin and streptomycin $(\mathrm{P}>0.01)$ Table 5. Again, $0.85 \mathrm{ug} / \mathrm{ml}$ concentration remains a choiced concentration even after 18 hours incubation after treatment.

The only dose that was recorded as a significant $(\mathrm{P}<0.05)$ sensitivity enhancer after 24hours incubation was $0.35 \mathrm{ug} / \mathrm{ml}$. There was no highly significant enhancer after this period of incubation. The fact that 0.85 and $0.95 \mathrm{ug} / \mathrm{ml}$ concentrations maintained their highly significant status $(\mathrm{P}<0.01)$ in terms of sensitivity enhancement at 6hours, 12 hours and partly 18 hours incubation after treatment tends to suggest a maximum incubation period of 18hours (not 24hours) of sensitivity testing in order to obtain optimal or maximum sensitivity reactions (i.e., zones of inhibition). Moreover, after 24hours incubation, the other eight antibiotics namely ciprofloxacin, ceftazidime, nalidixic acid, gentamicin, cefixime, ofloxacin, augmentin, pefloxacin and ampicillin remained resistant even after curing treatment with homodium bromide. It may be that the genes coding for their resistance markers may be carried on chromosomes (chromosome mediated) or non-conjugative plasmids (Akortha and Filgona, 2009).

The consistent resistance of MDR E.coli to ciprofloxacin after treatment and 24hours incubation in this study was particularly noted. Also noted, was overuse of chloroquine for malaria treatment by patient (from whom isolate was obtained) may be a likely cause of this (Mark, 2008).

Sensitivity enhancement effect of the non-toxic laboratory or sub-inhibitory concentrations of homodium bromide on the minimum inhibitory concentration (MIC) of gentamicin (one of the three sensitivity enhanced antibiotics) as it affected MDR E.coli showed a four-fold, two-fold, two-fold, fourfold and four-fold reductions in MIC of gentamicin as recorded for 0.35, 0.45, 0.75, 0.85 and $0.95 \mathrm{ug} / \mathrm{ml}$ homodium bromide concentrations respectively (Table 10). A fast and accurate determination of MIC can ensure optimal effective treatment of patients while at the same time, avoiding over-prescription. This will save money for the healthcare provider as well as reducing development of resistance (NCCLS, 2000; MacGowan and Wise, 2001).

Gentamicin from long standing research has an MIC of 10ug. This MIC was reduced to 2.5ug by homodium bromide treatment of $0.35 \mathrm{ug} / \mathrm{ml}$. Similarly, concentration treatments of $0.45,0.75,0.85$ and $0.95 \mathrm{ug} / \mathrm{ml}$ resulted in MIC reductions to $5 \mathrm{ug}$, 5ug, $2.5 \mathrm{ug}$ and $2.5 \mathrm{ug}$ respectively. The implication of this is that when sub-inhibitory doses of $0.35,0.85$ and $0.95 \mathrm{ug} / \mathrm{ml}$ (particularly the last two) are incorporated into the manufacture of gentamicin, the drug when administered, may produce better results in terms of cure of a disease as it will require four times its concentrations to function in vivo. In a similar work, Kohler (2010) showed that the resistance of Pseudomonas aeruginosa to tetracycline efflux was reduced from MIC $0.032 \mathrm{ug} / \mathrm{ml}$ to $0.004 \mathrm{ug} / \mathrm{ml}$ (eight-fold reduction) by treatment with phenothiazine. Crowle et al. (1992) demonstrated that non-toxic concentrations of phenothiazines in the lungs achieved complete elimination of Mycobacterium tuberculosis from human macrophages.

Mean percentage sensitivity enhancements of $171.7 \%, 138.9 \%, 57.4 \%$ and $50.8 \%$ of multidrug $\mathrm{EC}_{8}$ strain to gentamicin, nitrofurantoin and streptomycin at 6,12,18 and 24hours incubation showed clearly that the highest enhancement was obtained at 6hours incubation after treatment with homodium bromide. Moreso, taking into account that significant sensitivity enhancement $(\mathrm{P}<0.05)$ and highly significant enhancement $(\mathrm{P}<0.01)$ produced by 0.85 and $0.95 \mathrm{ug} / \mathrm{ml} \mathrm{HmBr}$ at 6hours and 12 hours incubation only. This seems to suggest that 6hours incubation period is ideal for incooperation of these non-toxic concentrations of the chemical agent into antibiotics manufacture by the pharmaceutical industries (if they choose to adopt findings in this study) for optimal therapeutic performance of drugs when consumed. 
The ability of homodium bromide treatment to sensitize bacterial cells to such a heterogeneous group of antibiotics underlines the non-specific and potentially general nature of its enhancing activity (Byron et al., 2003). In vitro data obtained in this study revealed that sub-inhibitory homodium bromide could significantly sensitize MDR E.coli to some selected antibiotics.

Results also suggest a general role for the use of compounds like ethidium bromide (homodium bromide) as enhancer of non-specific bacterial permeability to antibiotics and antimicrobials. This compound may be useful especially in topical or surface applications where the required concentrations could be reasonably achieved. Moreso, the ability of homodium bromide treatment (at sub-inhibitory doses) to sensitize bacterial cells to such a heterogeneous group of antibiotics underlines the nonspecific and potentially general nature of its enhancing activity.

It is important to note that urinary tract infections due to E.coli has been and is still a health problem and in order to maintain effective therapy, it is imperative to monitor susceptibility data as resistant infectious pathogens are continually emerging and resistance trends should be kept under check through intensive research and antibiotic resistance surveillance (Akortha and Filgona, 2009). This could lead to novel and alternative drug therapies as well as implementation of preventive measures on the proliferation of antibiotic resistance among pathogenic bacteria.

It is hereby recommended that further studies should be done to isolate Escherichia coli from urine of female patients and carry out sensitivity enhancement treatment on multidrug strains. Results could be compared with those of present study statistically for possible correlations or deviations.

\section{REFERENCES}

[1]. Akortha, E.E and Filgona, J. (2009). Transfer of gentamicin resistance genes among enterobacteriaceae isolated from the outpatients with urinary tract infections attending 3 hospitals in Mubi, Adamawa State. Scientific Research and essay. 4(8): 745-752.

[2]. Baquero, F., Garcia, J.A and Aguilar, L. (1999). Antimicrobial resistance of 1113 Streptococcus pneumoniae isolates from patients with respiratory tract infections in Spain. Antimicrob. Agents Chemother 43: 357-359.

[3]. Beg, A.Z and Ahmad, I. (2000). Effect of plumbago zeylanica extract and certain curing agents on multidrug resistant bacteria of clinical origin. World J. Microbiol. Biotech. 16: 841-844.

[4]. Bergeron, M.G. (1995). Treatment of pyelonephritis in adults. Med. Clin. N. Am. 75: 619649.

[5]. Byron, F., Brehm, S and Eric, A.J. (2003). Sensitization of Staphylococcus aureus and Escherichia coli to antibiotics by the sesquiterpenoids. Antimicrob. Agents Chemother. 47(10): 3357-3360.

[6]. Carlton, B.C and Brown, B.J. (1981). Gene mutation In: Manual Methods of General Bacteriology. American Society of Microbiology Press, Washington DC, USA. 242p. 
[7]. Chakrabarthy, P.K., Mishra, A.K and Chakrabarti, S.K. (1984). Loss of plasmid-linked drug resistance after treatment with iodo-deoxyuridine. Indian Journ. Expt. Biol. 22: 333-334.

[8]. Cohen, M.L. (1992). Epidemiology of drug resistance: implications for a post-antimicrobial era. Science. 257: 1050-1055.

[9]. Crowle, A.J., Douvas, S.G and May, M.H. (1992). Chlorpromazine: a drug potentially useful for treating Mycobacterial infections: Chemotherapy. 38: 410-419.

[10]. Danilevskaya, O.N and Gragerov, A.I. (1980). Curing of Escherichia coli plasmids by coumermycin. Mol. General Genetics. 178: 133-235.

[11]. Droge, M., Puhler, A and Selbitschka, W. (1998). Horizontal gene transfer as a biosafety issue: A natural phenomenon of public concern. Journ. Biotech. 64: 75-90.

[12]. Evans, J.R., Doyle, J and Dolores, G. (2007). Medical Microbiology, $4^{\text {th }}$ edn. The University of Texas Medical Branch at Galveston. 551p.

[13]. Fuji, N., Yamashita, M., Nagashima, M and Nakano, H. (1992). Induction of topoisomerase II mediated DNA cleavage by the plant naphthoquinones plumbagin and Shikonin. Anti. Agents Chemother. 36: 2589-2594.

[14]. Gupta,T.D., Bandyopathy, T., Dastidar, S.G., Bandopadhyay, M., Mistra, A and Chakrabarty, A.N. (1980). R plasmids of Staphylococcus and their elimination by different agents. Indian Journ. Exp. Biol. 18: 478-481.

[15]. Gutmann, L. (1985). Cross-resistance to nalidixic acid, trimethoprim and chloramphenicol associated with alterations in the outer membrane proteins of Klebsiella, Enterobacter and Serratia. Journ. Infect. Dis. 151: 501-507.

[16]. Jan, M.B., John, D.T and SENTRY PAC. (2004). High prevalence of oxacillin resistant Staphylococcus aureus isolates from hospitalized patients in asia-pacific and South Africa: Results from SENTRY antimicrobial surveillance program, 1998-1999. Antimicrob Agent Chemother. 46: 879-881.

[17]. Jenks, P.J., Hu, Y.M., Daniel, F., Mehtar,S and Livermore, D.M. (1995). Plasmid mediated production of class I (Amp C) Beta lactamase by two Klebsiella pneumoniae. Journ Antimicrob. Chemother. 35: 235-236.

[18]. Johnson, J., Kuskowski, M., Menard, M., Gajewski, A., Xercavins, M and Garau, J. (2006). Similarity between human and chicken Escherichia coli isolates in relation to ciprofloxacin resistance status. Journ. Infect. Dis. 194(1): 71-78.

[19]. Kohler, N.O. (2010). Non-antibiotics Reverse Resistance of Bacteria to Antibiotics in vivo. Journ. Antimicrob. Chemother. 24(5): 751-754.

[20]. Lakshmi, V.V., Padma, S and Polasa, H. (1989). Loss of plasmid antibiotic resistance in Escherichia coli on treatment with some compounds. FEMS Microbiol. Lets. 57: 275-278. 
[21]. Lewis, K. (1994). Multidrug resistance pump in bacteria: variation on a theme. Trends Biochem. Sci. 19: 119-123.

[22]. Li, X.Z., Poole, K and Nikaido, H. (2004). Contributions of MexAB-OprM and EmrE homolog to intrinsic resistance of Pseudomonas aeruginosa to aminoglycosides and dyes. Antimicrob. Agents Chemother. 47: 27-33.

[23]. Madigan, M., Martinko, J and Parker, J. (2003). Brock Biology of Microorganisms (10 ${ }^{\text {th }}$ edn). Prentice Hall, Upper Saddle River, NJ. USA, 500p.

[24]. May, J.W., Houghton, R.H and Perret, C.J. (1964). The effect of growth at elevated temperatures on some heritable properties of Staphylococcus aureus. Journ. Gen. Microbiol. 37: 157-169.

[25]. Mark, N. (2008). Malaria drug contributing to antibiotic resistance. Science Development Network.

[26]. McGowan, J.E. (2006). Resistance in non-fermenting gram negative bacteria: multidrug resistance to the maximum. American Journ. Infect. Control. 34: 29-37.

[27]. McGowan, A.P and Wise, R. (2001). Establishing MIC breakpoints and the interpretation of invitro susceptibility tests. Journ. Antimicrob. Chemother. 48: 17-28.

[28]. NCCLS (2000). Methods for Dilution, Antimicrobial Susceptibility Tests for Bacteria that grow aerobically: Approved Standard ( $5^{\text {th }}$ edn). Wayne, PA, USA.

[29]. Neu, H.C. (1989). Overview of mechanisms of bacterial resistance. Diag. Microbiol. Infect. Dis. 12: 109-116.

[30]. Obaseki-Ebor, E.E. (1984). Rifampicin curing of plasmids in Escherichia coli K12 rifampicin resistant host. Journ. Pharm. Pharmacol. 36: 467-470.

[31]. Okeke, I.N., Lamikanra, A and Edelman, R. (1999). Socio-economic and behavioral factors leading to acquired bacterial resistance to antibiotics in developing countries. Emerging Infectious Diseases. 5: 18-27.

[32]. Oskay, M., Oskay, D and Kalyoneu, F. (2009). Activity of some plant extracts against multidrug resistant human pathogens. Iranian Journ of Pharm. Resear. 8(4): 293-300.

[33]. Paterson, D.L and Bonomo, R.A. (2005). Extended spectrum beta-lactamase: a clinical update. Clin. Microbiol. Rev. 18(4): 657-686. Doi. 101.1128/ CMR.18.4.

[34]. Perfeito, L, Fernandes, L., Mota, C and Gordo, I. (2007). Adaptive Mutations in Bacteria: High Rate and Small Effects. Science. 317(5839): 813-815. Doi: 10.1126/Science. 1142284.

[35]. Piddock, L.J. (2006). Clinically relevant chromosomally encoded multidrug resistance efflux pumps in bacteria. Clin. Microbiol. Rev. 19:382-402.

[36]. Poppe, C and Gyles, C.L. (1988). Tagging and elimination of plasmids in Salmonella of avian origin. Vet. Microbiol. 18: 73-87. 
[37]. Ramchandani, M., Manges, A.R., Debroy, C., Smith, S.P., Johnson, J.R and Riley, L.W. (2005). Possible animal origin of human-associated multidrug resistant uropathogenic Escherichia coli. Clin. Infect. Dis. 40: 251-257.

[38]. Ramesh, A., Halami, P.M and Chandrashekar, A. (2000). Ascorbic acid-induced loss of a pediocin-encoding plasmid in Pediococcus acidilactici CFR K7. World Journ. Microbiol. Bio. 16: 695-697.

[39]. Reddy, G., Shridhar, P and Polasa, H. (1986). Elimination of Col. E1 (pBR322 and pBR329) plasmids in Escherichia coli on treatment with hexamine ruthenium III chloride. Curr. Microbiol. 13: 243-246.

[40]. Robertson, G.T., Doyle, T.B and Lynch, A.S. (2005). Use of an efflux- deficient Streptococcus pneumoniae strain panel to identify ABC-Class multidrug transporters involved in intrinsic resistance to antimicrobial agents. Antimicrob. Agents Chemother. 49: 4781-4783.

[41]. Ruiz-Barba, J.L., Piard, J.C and Jimenez-Diaz, R. (1991). Plasmid profiles and curing of plasmids in Lactococcus plantarum strains isolated from green olive fermentations. Journ. Appl. Bacteriol. 71: 417-421.

[42]. Salisbury, V., Hedges, R.W and Datta, N. (1972). Two modes of curing transmissible plasmids. Journ. Gen. Microbiol. 70: 443-452.

[43]. Salyers, A.A and Amabile-Cuevas, C.F. (1997). Why are antibiotic resistance genes so resistant to elimination? Ant. Ag Chemo. 41(11): 2321-2325.

[44]. Stanisich, V.A.(1984). Identification and analysis of plasmids at genetic level. Met. Microbiol. 17: 6-32.

[45]. Stadler, J and Adelberg, E.A. (1972). Temperature dependence of sex-factor maintenance in Escherichia coli K12. Journ. Bacteriol. 109: 447-449.

[46]. Stavril, M., Laura, J.V., Piddock, V and Gibbons, S. (2007). Bacterial efflux pumps inhibitors from natural sources. Journ. Of Antimicrob. Chemother 59(16): 1247-1260.

[47]. Tenover, F.C. (2006). Mechanism of antimicrobial resistance in bacteria. Am. Journ. Med. 119(6): 3-10.

[48]. Todar, K. (2007). Pathogenic E.coli in online Textbook of Bacteriology. University of Wisconsin-Madison Press. 30p. http/www.textbookofbacteriology.net.

[49]. Tomoeda, M., Inuzuka, M., Kubo, N and Nakamura, S. (1968). Effective elimination of drug resistance and sex factor in Escherichia coli by sodium dodecyl sulphate. Journ. Bacteriol. 95: 1078-1089.

[50]. Trevors, J.T. (1986). Plasmid curing in bacteria. FEMS Microbiol. Rev. 32(3): 149-157.

[51]. Viljanen, P and Boratynski, J. (1991). The susceptibility of conjugative resistance transfer in gram negative bacteria to physico-chemical and biochemical agents. FEMA Microbiol. Rev. $88: 43-54$. 
[52]. Woo, P.C.Y., Lau, S.K.P and Yuen, K.Y. (2003). Facilitation of horizontal transfer of antimicrobial resistance by transformation of antibiotic-induced cell wall-deficient bacteria. Med. Hypot. 61(4): 503-508.

[53]. World Health Organization. (2012). Antimicrobial resistance in the European Union and the World. Lecture delivered by Dr Margaret Chan, Director-General of WHO at the Conference on Combating antimicrobial resistance: time for action. Copenhagen, Denmark, March $14^{\text {th }}$, 2012.

[54]. Wurmb-Schwark, N., Cavelier, L and Cortopassi, G.A. (2006). A low dose of ethidium bromide leads to an increase of total mitochondrial DNA while higher concentrations induce the mtDNA 4997 deletion in a human neuronal cell line. Mutat. Res. 596(2): 57-63. Doi: 10.1016/J.mrfmmm. 2005.12.003.

[55]. Zielenkiewicz, U and Ceglowski, P. (2001). Mechanisms of plasmid stable maintenance with special focus on plasmid addiction systems. Acta. Bio. Polo. 48(4): 1003-1023.

[56]. Zhan, W.H., Hu, Z.O., Hara, Y and Shimamura, T. (2001). Inhibition by epigallocatechin gallate (ECGg) of conjugative R plasmid transfer in Escherichia coli. Journ. Infect. Chemo. 7: 195-197. 